\title{
Treatment with synthetic $\beta$-lactoglobulin peptides can prevent clinical symptoms in a mouse model for cow's milk allergy
}

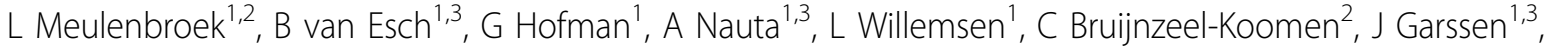 \\ E van Hoffen ${ }^{2}, L$ Knippels ${ }^{1,3^{*}}$
}

From Food Allergy and Anaphylaxis Meeting (FAAM 2013)

Nice, France. 7-9 February 2013

\section{Background}

Previous animal studies showed that partial whey hydrolyates could prevent acute allergic symptoms in a mouse model for cow's milk allergy. This effect was even more pronounced in combination with a diet containing a specific non-digestible oligosaccharide mixture of scGalacto- (scGOS), lc-Fructo- (lcFOS) and Acidic- (pAOS) oligosaccharides (in a 9:1:2 ratio). We hypothesized that these hydrolysates contain peptides that can induce the observed tolerance. Therefore we investigated the potential of synthetic $\beta$-lactoglobulin peptides, with or without a diet containing ScGOS/lsFOS/pAOS, to induce tolerance in this mouse model.

\section{Methods}

Female $\mathrm{C} 3 \mathrm{H} / \mathrm{HeOuJ}$ mice were treated for six consecutive days with three synthetic $\beta$-lactoglobulin peptide mixes or PBS. The peptides were selected based on human T cell proliferation data and previous literature. During this treatment period, mice were fed a control or sc GOS/ lcFOC/pAOS containing diet. Subsequently, mice were sensitized five times with cholera toxin alone or in combination with whey and received an intradermal ear and oral challenge 6 days later.

\section{Results}

Treating the mice with peptide mix 1 and 3 before sensitization reduced the acute allergic ear response. Peptide mix 2 showed no effect. The effect of peptide mix 1 was stronger in combination with the scGOS/lcFOS/pAOS containing diet. No additional effects were observed for the other

Pharmacology, Utrecht Institute for Pharmaceutical Sciences, Utrecht, the Netherlands

Full list of author information is available at the end of the article mixes. Some mice showed reduced antibody responses but no association with clinical responses was observed. Of the peptides in mixture 1 , one peptide showed the strongest effect on the acute allergic skin response. This peptide also tends to decrease whey-specific antibody levels and to increase the percentages of $\mathrm{CD} 11 \mathrm{~b}+\mathrm{CD} 103+$ dendritic cells and CD25+Foxp3+ T cells in the MLN.

\section{Conclusion}

Pre-treatment with specific $\beta$-lactoglobulin peptides is able to reduce the acute allergic response in a mouse model for cow's milk allergy suggesting that specific peptides are capable of inducing tolerance which may involve regulatory dendritic and $\mathrm{T}$ cells. The tolerizing capacity could be enhanced by the addition of a scGOS/lcFOS/pAOS containing diet. Further research is necessary to determine whether these peptides are present in the tolerance inducing hydrolysates and the mechanism of action of these peptides should be further investigated.

\section{Disclosure of interest}

L Meulenbroek: None declared, B van Esch: Employee of Danone Research Centre for Specialised Nutrition, G Hofman: None declared, A Nauta: Employee of Danone Research Centre for Specialised Nutrition, L Willemsen: None declared, C Bruijnzeel-Koomen: None declared, J Garssen: Employee of Danone Research Centre for Specialised Nutrition, E van Hoffen: None declared, L Knippels: Employee of Danone Research Centre for Specialised Nutrition.

\section{Author details}

${ }^{1}$ Pharmacology, Utrecht Institute for Pharmaceutical Sciences, Utrecht, the Netherlands. ${ }^{2}$ Dermatology/Allergology, University Medical Center Utrecht, 
Published: 25 July 2013

doi:10.1186/2045-7022-3-S3-P83

Cite this article as: Meulenbroek et al:: Treatment with synthetic

$\beta$-lactoglobulin peptides can prevent clinical symptoms in a mouse model for cow's milk allergy. Clinical and Translational Allergy 2013

3(Suppl 3):P83.

Submit your next manuscript to BioMed Central and take full advantage of:

- Convenient online submission

- Thorough peer review

- No space constraints or color figure charges

- Immediate publication on acceptance

- Inclusion in PubMed, CAS, Scopus and Google Scholar

- Research which is freely available for redistribution 